\title{
PENGEMBANGAN LKPD BERBASIS PENDEKATAN SAINTIFIK PADA MATERI SPLDV KELAS VIII SMP NEGERI 5 LUBUKLINGGAU
}

\author{
Vina Bahrilin ${ }^{1}$, Maria Luthfiana ${ }^{2}$, Efuansyah ${ }^{3}$ \\ Program Studi Pendidikan Matematika STKIP PGRI Lubuklinggau ${ }^{1,2,3}$ \\ vinabahrilin10pin@gmail.com ${ }^{1}$
}

\begin{abstract}
ABSTRAK
Penelitian ini bertujuan untuk mengembangkan lembar kerja peserta didik (LKPD) berbasis pendekatan saintifik pada materi sistem persamaan linear dua variabel (SPLDV) di kelas VIII sesuai dengan kurikulum 2013. Penelitian ini merupakan penelitian pengembangan dengan menggunakan model 4-D yang terdiri dari 4 tahap yaitu: tahap Define, Design, Develop, dan Disseminate. Teknik pengumpulan data yang digunakan adalah angket validitas dan angket kepraktisan. Berdasarkan hasil analisis penilaian oleh keempat ahli yaitu: ahli bahasa, ahli materi, ahli media dan ahli isi menunjukkan bahwa lembar kerja peserta didik menggunakan pendekatan saintifik pada materi sistem persamaan linear dua variabel (SPLDV) memenuhi kriteria valid dengan rata-rata skor 3,37. Sedangkan hasil analisis penilaian lembar kepraktisan siswa yang terdiri dari 31 orang diperoleh bahwa lembar kerja peserta didik menggunakan pendekatan saintifik pada materi sistem persamaan linear dua variabel (SPLDV) memenuhi kriteria praktis dengan rata-rata skor 3,31.
\end{abstract}

Kata kunci : LKPD, pendekatan saintifik, SPLDV

\begin{abstract}
This study aims to develop student worksheets based on a scientific approach on the two-variable linear equation system (TVLES) topic in class VIII by the 2013 curriculum. This research is development research using the 4-D model which consists of 4 stages, namely: the Define stage, Design, Develop, and Disseminate. The data collection technique used was validity questionnaire and practicality questionnaire. Based on the results of the assessment analysis by the four experts, namely: linguists, material experts, media experts, and content experts, it shows that the worksheets of students using a scientific approach on two-variable linear equation system (TVLES) topic meet the valid criteria with an average score of 3.37. While the results of the analysis of student practicality sheet assessments consisting of 31 people, it was found that the worksheets met the practical criteria with an average score of 3.31.
\end{abstract}

Keywords : student worksheets, scientific approach, TVLES 


\section{PENDAHULUAN}

Pembelajaran dalam kurikulum 2013 menekankan pembelajaran yang mampu mengembangkan suatu kreativitas peserta didik (Ine, 2015:270). Mulyoto (2013:103) mengemukakan bahwa selama ini unsur kreativitas memang sering disebut pakar pendidikan, tetapi pembelajaran yang memberi ruang kepada peserta didik untuk mengembangkan kreativitas belum mendapat tempat. Di samping itu, Kementerian Pendidikan dan Kebudayaan (Kemendikbud) mengemukakan bahwa kurikulum 2013 juga mengamanatkan untuk dapat mendorong peserta didik supaya mampu menjadi lebih baik dalam melakukan observasi, bertanya, menalar, dan mengkomunikasikan terhadap apa yang mereka peroleh atau mereka ketahui setelah menerima materi pembelajaran (Kemendikbud, 2013:3). Inti yang menjadi ciri khas pembelajaran dengan menggunakan kurikulum 2013 adalah pembelajaran yang menggunakan pendekatan saintifik yang saat ini tentunya menarik untuk dipelajari dan diteliti lebih lanjut oleh para peserta didik maupun pemerhati pendidikan (Ine, 2015:271).

Menurut Rusman (2017:422), pendekatan saintifik adalah sebuah pendekatan pembelajaran yang menekankan siswa dapat aktif melalui kegiatan-kegiatan mengamati, menanya, menalar, mencoba dan membuat jejaring pada setiap kegiatan pembelajaran yang ada di sekolah. Hal yang hampir sama juga dikemukakan Hosnan (2014:23), bahwa pendekatan saintifik adalah suatu proses pembelajaran yang telah dirancang sedemikian rupa agar peserta didik dapat aktif membangun konsep, hukum atau prinsip melalui tahapan mengamati, merumuskan masalah, merumuskan hipotesis, mengumpulkan data dengan bermacam-macam teknik, menganalisis data, menarik kesimpulan dan mengkomunikasikan konsep, hukum atau prinsip yang ditemukan. Salah satu pendekatan pembelajaran dalam penerapan kurikulum 2013 di sekolah, guru harus menggunakan pendekatan saintifik dan pendekatan ini lebih efektif hasilnya dibandingkan pendekatan tradisional dikarenakan pendekatan saintifik dapat membuat siswa lebih aktif dan kreatif dalam pembelajaran (Shoimin, 2014:164).

Berdasarkan hasil observasi dan wawancara pada hari Selasa 15 Januari 2019 yang dilakukan dengan salah satu guru matematika SMP Negeri 5 Lubuklinggau pada mata pelajaran matematika yang menyatakan bahwa pihak sekolah sudah menggunakan Kurikulum 2013 sejak tiga tahun belakangan ini. Namun, terdapat beberapa kendala dalam penerapan pembelajaran dengan menggunakan kurikulum 2013 diantaranya kurangnya sarana dan prasarana, salah satunya bahan ajar. Bahan ajar itu sendiri adalah bagian yang sangat penting dari suatu proses pembelajaran (Ramdani, 2012:50). Bahan ajar yang digunakan di sekolah tersebut diantaranya Buku paket Kurikulum 2013 dan lembar kerja siswa (LKS) dimana buku paket tersebut sebagai sumber belajar utama sedangkan lembar kerja siswa (LKS) sebagai pendamping buku paket tersebut dan LKS yang digunakan di sana juga memiliki beberapa kekurangan diantaranya LKS yang digunakan tidak sesuai dengan Kurikulum 2013, tidak berwarna dan terlalu banyak soal yang cenderung panjang, sehingga proses pembelajaran tidak menarik dan membuat peserta didik mudah bosan dalam proses pembelajaran yang mengakibatkan peserta didik sulit memahami materi yang diajarkan, terutama pada materi Sistem Persamaan Linier Dua Variabel (SPLDV) siswa terkadang memiliki kesulitan dalam memahami materi karena isi dari LKS yang digunakan tidak sesuai dengan kehidupan di sekitar peserta didik.

Oleh sebab itu dibutuhkan bahan ajar yang menggunakan pendekatan yang sesuai dengan kurikulum 2013, yang menarik dan memberikan siswa keluasan dalam 
berpikir dan pemikiran matematis siswa dapat berkembang. Siswa dapat meningkatkan kemampuan berpikir dan kemampuan komunikasi matematisnya melalui bahan ajar. Bahan ajar yang digunakan yaitu Lembar Kerja Peserta Didik (LKPD).

Menurut Istikharah dan Simatupang (2017:32), LKPD merupakan salah satu bentuk bahan ajar yang berbentuk media cetak dalam implementasi Kurikulum 2013. LKPD diharapkan dapat menjadi salah satu alternatif dalam melengkapi bahan ajar pada pembelajaran kurikulum 2013 supaya pembelajaran dapat berjalan dengan baik dan sesuai dengan tujuan yang diharapkan pada Kurikulum 2013. Hal yang tidak jauh berbeda diungkapkan oleh Devi dkk (2009:32), LKPD adalah lembaranlembaran yang berisi tugas-tugas yang harus dikerjakan oleh peserta didik, dimana lembarannya berisi petunjuk dan langkah-langkah untuk menyelesaikan tugas. Untuk LKPD ada dua hal yang harus diperhatikan dan dikerjakan diantaranya yaitu mengikuti langkah-langkah penyusunan dan memperhatikan aturan-aturan penyusunan LKPD sebagai media handout pembelajaran.

Lembar kerja peserta didik (LKPD) adalah lembaran kerja yang berisi petunjuk langkah kerja sesuai dengan strategi yang dirancang agar mampu meningkatkan kemampuan komunikasi siswa. Lembar Kerja Peserta Didik (LKPD) sebaiknya disusun sendiri oleh guru karena gurulah yang tahu bagaimana karakter siswa, namun masih banyak guru yang belum mengembangkan Lembar Kerja Peserta Didik (LKPD) dalam proses pembelajarannya. Maka perlu adanya pengembangan Lembar Kerja Peserta Didik (LKPD) yang menarik, efektif dan praktis (Pansa, 2017:231)

Berdasarkan uraian di atas, dicoba untuk mengembangkan Lembar Kerja Peserta Didik (LKPD) Berbasis Pendekatan Saintifik pada Materi Sistem Permasalahan Linier Dua Variabel (SPLDV) Kelas VIII.

\section{METODE}

Metode penelitian yang digunakan dalam penelitian ini adalah metode research and development (R\&D). Penelitian ini menghasilkan produk bahan ajar berupa Lembar Kerja Peserta Didik (LKPD) menggunakan pendekatan saintifik pada materi sistem persamaan linear dua variabel (SPLDV). Desain dan pengembangan LKPD menggunakan pendekatan model 4-D, yaitu define (pendefinisian), design (perancangan), develop (pengembangan) dan disseminate (penyebaran). Namun tahap disseminate tidak dilakukan karena hanya fokus pada pencapaian tujuan penelitian pengembangan yaitu pada aspek valid, praktis dan memiliki efek potensial. Hasil LKPD ini dikatakan baik apabila memenuhi kriteria valid, praktis dan memiliki efek potensial.

\section{1) Tahap define}

Tahap ini merupakan tahapan melakukan analisis untuk menetapkan dan mendefinisikan kebutuhan-kebutuhan dalam pembelajaran. Tahap ini terdiri lima langkah, yaitu:

a) Analisis awal akhir

Bertujuan menentukan masalah yang dialami dalam pembelajaran. Tahap ini dilakukan dengan melakukan observasi dan wawancara pada salah satu guru matematika di SMP Negeri 5 Lubuklinggau terhadap pembelajaran materi Sistem Persamaan Linier Dua Variabel (SPLDV). Adapun yang dilakukan pada observasi dan wawancara yaitu: 1) Analisis kurikulum yang digunakan pada mata pelajaran matematika di SMP Negeri 5 Lubuklinggau, 2) Analisis masalah 
yang dihadapi siswa dan guru dalam kelas, 3) Analisis proses pembelajaran dan fasilitas yang digunakan dalam pembelajaran.

b) Analisis siswa

Bertujuan untuk mengetahui karakteristik siswa yang sesuai dengan rancangan dan perangkat pembelajaran. Tahap ini dilakukan dengan melakukan wawancara pada guru matematika di SMP Negeri 5 Lubuklinggau mengenai; 1) Situasi pembelajaran dan aktivitas siswa dalam pembelajaran, 2) Mencatat bahan yang disediakan guru dalam pembelajaran, 3) Mencatat media yang digunakan siswa dalam pembelajaran.

c) Analisis konsep

Bertujuan untuk mengidentifikasi konsep pokok yang diajarkan, merinci dan menyusunnya secara sistematis. Adapun yang dilakukan adalah membuat peta konsep materi Sistem Persamaan Linier Dua Variabel (SPLDV). Peta konsep menggambarkan sistematika materi yang akan disajikan pada bahan ajar.

d) Analisis tugas

Bertujuan untuk mengidentifikasi rincian tugas yang akan dikerjakan siswa di setiap pembelajaran. Adapun yang dilakukan antara lain: 1) Menentukan isi tugas yang akan diberikan, 2) Menentukan cara menyelesaikan, 3) Manajemen tugas (tugas tersebut dibahas secara klasikal atau dikoreksi bersama guru).

e) Perumusan tujuan pembelajaran

Dilakukan untuk menetapkan tujuan pembelajaran melalui pendekatan saintifik berdasarkan hasil analisis konsep dan analisis tugas.

\section{2) Tahap design}

Tahap ini bertujuan untuk menghasilkan rancangan awal LKPD. Pada tahap ini akan dihasilkan rancangan awal (prototype I) LKPD menggunakan pendekatan saintifik. Tahapan design yang akan digunakan dalam membuat LKPD menggunakan pendekatan saintifik adalah sebagai berikut.

a) Penyusunan tes acuan patokan

Penyusunan tes acuan patokan dilakukan atas dasar hasil perumusan dari tujuan pembelajaran yang menjadi tolak ukur kemampuan peserta didik dalam menyelesaikan bentuk soal yang disajikan di LKPD yang dikaitkan dengan lingkungan yang ada di sekitar peserta didik.

b) Pemilihan media

Pemilihan media yang sesuai dengan pendekatan saintifik yaitu berupa LKPD, LKPD ini sebagai sarana dalam menyampaikan pembelajaran atau informasi mengenai pemahaman konsep siswa.

c) Pemilihan format

Selanjutnya memilih format yang sesuai dengan kebutuhan peserta didik berdasarkan kompetensi dasar materi Sistem Persamaan Linear Dua Variabel (SPLDV), yaitu (1) KD 3.5 Menjelaskan sistem persamaan linear dua variabel dan penyelesaiannya yang dihubungkan dengan masalah kontekstual, (2) KD 4.5 Menyelesaikan masalah yang berkaitan dengan sistem persamaan linear dua variabel. Sebagaimana LKPD yang akan dikembangkan meliputi beberapa komponen yaitu bagian awal, bagian isi, dan bagian akhir.

d) Desain awal LKPD

Tahap desain awal LKPD adalah tahap yang meliputi penulisan, penelaahan, dan pengadaptasian perangkat pembelajaran berdasarkan acuan patokan, pemilihan media, dan format yang ditetapkan oleh perancang. Tahap 
perancangan tersebut yaitu; 1) Menentukan judul atau tema yang akan digunakan, 2) Pengantar dan tujuan pembuatan LKPD, 3) Petunjuk LKPD yaitu kegiatan dalam LKPD ini dikerjakan secara individu maupun berdiskusi, 4) Menyusun peta kebutuhan konsep, 5) Melakukan analisis kurikulum demi menentukan KD untuk memudahkan tercapainya kegiatan pembelajaran, 6) Materi sesuai judul, 7) Kesimpulan.

Dari tahap rancangan LKPD tersebut maka LKPD yang dihasilkan akan menghasilkan prototype I, yang kemudian akan dikembangkan.

\section{3) Tahap develop}

Tahap develop (mengembangkan), bertujuan untuk memodifikasi produk yang dikembangkan dengan melakukan evaluasi dan revisi. Adapun yang dilakukan pada tahap ini yaitu; 1) Melakukan validasi Lembar Kerja Peserta Didik (LKPD) oleh dosen ahli materi, ahli bahasa, ahli media dan one to one, 2) Setelah divalidasi dan direvisi, kemudian dilakukan uji kepraktisan dengan cara mengujicobakan LKPD pada situasi nyata di kelas yaitu melalui tahap ujicoba kelompok kecil 6 siswa, setelah direvisi maka didapatkan prototype III. (a) Pada prototype III dilakukan ujicoba kelompok besar. (b) Setelah uji validasi dan kepraktisan maka karakteristik LKPD yang dikembangkan diperoleh berdasarkan analisis kevalidan dan kepraktisan, dimana LKPD yang dikembangkan dikatakan valid dan praktis apabila $X \geq 2,8$ sehingga diperoleh Lembar Kerja Peserta Didik (LKPD) menggunakan pendekatan saintifik yang valid, praktis dan memiliki karakteristik.

Penelitian ini dilaksanakan pada semester genap 2019/2020. Teknik pengumpulan data yang digunakan adalah angket validitas dan angket kepraktisan. Data yang digunakan dalam penelitian ini berupa data kuantitatif yang kemudian diubah ke dalam bentuk data kualitatif. Data kuantitatif tersebut diperoleh dari: (1) hasil validasi LKPD oleh validator dan (2) hasil angket kepraktisan oleh siswa. Hasil validasi digunakan untuk menentukan aspek kevalidan LKPD dan hasil angket kepraktisan digunakan untuk menentukan aspek kepraktisan LKPD.

Analisis kevalidan dilakukan dengan langkah-langkah sebagai berikut: (1) lembar validasi/angket untuk validator materi, validator bahasa, dan validator media menggunakan skala likert; (2) menghitung skor rata-rata dari seluruh aspek yang dinilai; (3) mengubah skor rata-rata seluruh aspek menjadi nilai kualitatif. Analisis kepraktisan dilakukan dengan menganalisis data angket kepraktisan dengan langkahlangkah hampir sama dengan analisis angket untuk validator.

\section{HASIL DAN PEMBAHASAN}

\section{1) Tahap define}

Hasil analisis pada tahap ini adalah sebagai berikut

a) Analisis awal akhir

Dilakukan observasi dan wawancara pada tanggal 15 Januari 2019 dengan salah satu guru matematika di SMP Negeri 5 Lubuklinggau kelas VIII. Hasil analisis awal yang diperoleh pada observasi dan wawancara yaitu; 1) Kurikulum yang digunakan pada mata pelajaran matematika di SMP Negeri 5 Lubuklinggau sudah mengacu pada Kurikulum 2013, 2) Masalah yang dihadapi dalam pembelajaran adalah siswa sangat bergantung kepada guru. Khusus pada SPLDV, siswa tampak kebingungan jika soal-soal yang diberikan berbeda dengan yang diajarkan karena siswa belum memahami konsep pada materi tersebut, 3) Sumber 
belajar yang digunakan adalah buku matematika kurikulum 2013. Namun buku tersebut tidak sepenuhnya menjadi sumber belajar yang digunakan dalam proses pembelajaran.

Pada tahap analisis akhir dilakukan pengembangan Lembar Kerja Peserta Didik (LKPD) menggunakan pendekatan saintifik pada materi Sistem Persamaan Linear Dua Variabel (SPLDV) dengan tujuan agar peserta didik memiliki wawasan pada lingkungan yang dapat dikaitkan dengan pembelajaran matematika khususnya pada materi Sistem Persamaan Linear Dua Variabel (SPLDV), peserta didik mampu menemukan dan memahami konsep-konsep yang ada pada materi tersebut serta mampu berpikir kreatif yang sesuai dengan tujuan dari kurikulum 2013.

b) Analisis siswa

Analisis ini bertujuan untuk mengetahui karakteristik siswa SMP Negeri 5 Lubuklinggau kelas VIII. Berdasarkan hasil observasi diperoleh informasi bahwa; 1) Siswa kelas VIII SMP Negeri 5 Lubuklinggau berusia antara 12-14 tahun, setiap siswa memiliki tingkat pengetahuan yang berbeda dan pengalaman belajar yang beragam, 2) Siswa kurang aktif dalam pembelajaran dan hanya menunggu penjelasan guru untuk memahami materi. Kebanyakan siswa kurang percaya diri untuk mengemukakan ide yang mereka miliki, 3) Bahan yang disediakan guru dalam pembelajaran berasal dari buku paket dan LKS yang sudah dibagikan ke siswa, dan 4) Media yang digunakan dalam pembelajaran khususnya pada materi Sistem Persamaan Linear Dua Variabel (SPLDV) belum memadai.

c) Analisis konsep

Pada tahap ini dilakukan kegiatan merinci dan menyusun secara sistematis konsep-konsep materi Sistem Persamaan Linear Dua Variabel (SPLDV) dengan membuat peta konsep materi tersebut.

d) Analisis tugas

Analisis tugas dilakukan untuk merinci tugas-tugas yang akan diberikan pada siswa. Hal-hal yang disajikan pada LKPD yang dikembangkan melalui analisis tugas yaitu; 1) Isi tugas yang diberikan pada materi Sistem Persamaan Linear Dua Variabel (SPLDV) didasarkan pada pembelajaran yang berbasis saintifik, 2) Masalah-masalah yang disajikan pada isi tugas tersebut berdasarkan kehidupan sehari-hari peserta didik khususnya pada proses jual-beli yang dilakukan peserta didik di sekolah maupun di luar sekolah, dimana penyelesaiannya sesuai dengan petunjuk yang diberikan, 3) Tugas-tugas yang diberikan pada LKPD secara garis besar dikerjakan melalui kegiatan diskusi dan melalui bimbingan dari guru.

e) Perumusan tujuan pembelajaran

Pada tahap ini bertujuan untuk merumuskan indikator-indikator pencapaian tujuan pembelajaran dengan menggunakan LKPD berdasarkan kurikulum 2013 pada materi Sistem Persamaan Linear Dua Variabel (SPLDV).

2) Tahap design

Pelaksanaan tahapan desain pengembangan Lembar Kerja Peserta Didik (LKPD) menggunakan pendekatan saintifik sebagai berikut:

a) Penyusunan format LKPD

Hal-hal yang perlu dilakukan dalam penyusunan format LKPD yaitu: (1) Menyusun Peta Kebutuhan LKPD, memberikan keterangan tentang banyaknya LKPD yang harus dibuat, (2) Menyusun Kerangka LKPD, LKPD yang 
dikembangkan terdiri dari tiga bagian, yaitu bagian awal, bagian isi, dan bagian akhir. Bagian awal terdiri dari halaman sampul depan, halaman identitas LKPD, kata pengantar, petunjuk penyajian LKPD, peta konsep dan daftar isi. Pada bagian isi, terdapat keseluruhan kegiatan yang dilakukan siswa untuk mendapatkan pengetahuan sesuai dengan KD materi sistem persamaan linear dua variabel (SPLDV). Sedangkan pada bagian akhir terdiri dari daftar pustaka dan halaman sampul belakang.

b) Pemilihan model/pendekatan penyajian

Dalam hal ini penyajian isi LKPD didasarkan pada pendekatan saintifik. Kegiatan pembelajaran disesuaikan dengan langkah-langkah pembelajaran menggunakan pendekatan saintifik juga serta masalah-masalah yang disajikan sesuai dengan kehidupan sehari-hari yang ada di sekitar peserta didik, yaitu proses jual-beli.

c) Desain awal LKPD

Desain LKPD menggunakan pendekatan saintifik disusun sesuai dengan karakteristik materi yang digunakan yaitu sistem persamaan linear dua variabel (SPLDV), dimana terdapat banyak gambar/ilustrasi yang digunakan dalam menyajikan materi tersebut. Gambar/ilustrasi yang digunakan tentunya berdasarkan kehidupan sehari-hari peserta didik dan dilengkapi kegiatan penemuan yang sesuai dengan langkah-langkah pendekatan saintifik agar siswa mampu menemukan dan memahami konsep-konsep yang terdapat pada materi sistem persamaan linear dua variabel.

\section{3) Tahap develop}

Tahap develop (mengembangkan) bertujuan untuk memodifikasi produk yang dikembangkan dengan melakukan evaluasi dan revisi sebelum menjadi produk yang valid dan praktis.

Prototype I LKPD yang dihasilkan pada tahap design diberikan pada pakar ahli (expert review) untuk divalidasi oleh validator bahasa, validator materi, dan validator media dan juga diberikan pada peserta didik secara perorangan (one to one). Hasil uji one to one digunakan untuk melihat kepraktisan produk, sedangkan hasil validasi ahli dianalisis untuk mengetahui aspek kevalidan.

Tabel 1. Rekapitulasi hasil penilaian para ahli

\begin{tabular}{ccccc}
\hline Validator & $\begin{array}{c}\text { Jumlah butir } \\
\text { pertanyaan }\end{array}$ & Skor yang diperoleh & $\begin{array}{c}\text { Skor rata-rata } \\
\text { ahli }\end{array}$ & Kategori \\
\hline Ahli bahasa & 14 & 42 & 3,00 & Valid \\
\hline Ahli materi & 22 & 79 & 3,60 & $\begin{array}{c}\text { Sangat } \\
\text { Valid }\end{array}$ \\
\hline Ahli media & 27 & 83 & 3,07 & Valid \\
\hline Ahli materi & 22 & 83 & 3,77 & $\begin{array}{c}\text { Sangat } \\
\text { Valid }\end{array}$ \\
\hline \multicolumn{2}{c}{ Jumlah } & 287 & 3,37 & Valid \\
\hline
\end{tabular}

Berdasarkan hasil analisis penilaian kevalidan LKPD oleh para ahli mendapatkan skor rata-rata sebesar 3,37 yang dikategorikan valid dan layak untuk diujicobakan dengan beberapa saran sebagai dasar untuk melakukan revisi. 
Tabel 2. Hasil analisis walkthrough para validator

\begin{tabular}{clc}
\hline Validator & \multicolumn{1}{c}{ Komentar dan saran } & \multicolumn{1}{c}{ Keputusan } \\
\hline Ahli bahasa & $\begin{array}{l}\text { Cek kembali perkata dan hubungan antar } \\
\text { kalimat }\end{array}$ & LKPD direvisi sesuai saran \\
\cline { 2 - 3 } & Usahakan identitas LKPD harus lengkap & LKPD direvisi sesuai saran \\
\hline Ahli materi 1 & $\begin{array}{l}\text { Usahakan pada bagian mencoba cukup } \\
\text { satu pada setiap sub materi }\end{array}$ & LKPD direvisi sesuai saran \\
\hline Ahli materi 2 & $\begin{array}{l}\text { LKPD yang dibuat sudah sangat baik dan } \\
\text { dapat digunakan untuk peserta didik }\end{array}$ & LKPD dipertahankan \\
& $\begin{array}{l}\text { karena sudah sesuai dengan kurikulum } \\
\text { 2013 dan sesuai dengan lingkungan } \\
\text { peserta didik }\end{array}$ \\
\hline Ahli media & $\begin{array}{l}\text { Karakteristik cover LKPD harus sesuai } \\
\text { dengan materi dan pendekatan }\end{array}$ & LKPD direvisi sesuai saran \\
\cline { 2 - 4 } & $\begin{array}{l}\text { Peta konsep dan petunjuk penyajian } \\
\text { diberi nomor urut }\end{array}$ & LKPD direvisi sesuai saran \\
\hline
\end{tabular}

Hasil ujicoba perorangan (one to one) yang terdiri dari 3 siswa (1 siswa berkemampuan sedang, 1 siswa berkemampuan rendah, dan 1 siswa berkemampuan tinggi) mendapatkan skor rata-rata 3,69, sehingga LKPD bisa diujicobakan pada tahap selanjutnya. Setelah divalidasi dan direvisi sesuai dengan komentar dan saran yang diberikan, maka menghasilkan prototype II.

Prototype II LKPD selanjutnya diujicobakan pada situasi nyata di kelas yaitu ujicoba kelompok kecil (small group) untuk melihat aspek kepraktisan dari penggunaan LKPD dan sebagai pertimbangan mengambil keputusan untuk diujicobakan pada kelompok besar. LKPD diujicobakan pada kelompok kecil yang terdiri dari 6 peserta didik yang memiliki kemampuan sedang, rendah dan tinggi untuk mengetahui kepraktisan LKPD berdasarkan skor angket. Hasil dari ujicoba kelompok kecil mendapat skor rata-rata 3,38 sehingga LKPD bisa diujicobakan pada kelompok besar di SMP Negeri 5 Lubuklinggau. LKPD direvisi kembali dan dievaluasi. Komentar dan saran peserta didik digunakan untuk bahan pertimbangan merevisi prototype III LKPD.

Prototype III LKPD diujicobakan pada kelompok besar (field test) dengan tujuan untuk mengetahui kelayakan LKPD ditinjau dari aspek kepraktisan. Angket peserta didik diberikan untuk melihat aspek kepraktisan tersebut. LKPD diujicobakan pada kelompok besar di SMP Negeri 5 Lubuklinggau dengan melibatkan 31 peserta didik kelas VIII.3. Pembelajaran dilakukan dengan menggunakan RPP dan LKPD menggunakan pendekatan saintifik pada materi sistem persamaan linear dua variabel (SPLDV). Terakhir, peserta didik dibagikan angket untuk mendapatkan data kepraktisan dari LKPD yang telah diujicobakan. Berdasarkan hasil analisis data penilaian kepraktisan LKPD menunjukkan skor ratarata sebesar 3,31 dengan kategori praktis. Dengan demikian, LKPD yang dikembangkan dapat digunakan dan memudahkan peserta didik dalam kegiatan pembelajaran pada materi sistem persamaan linear dua variabel (SPLDV). 
Berikut ini cuplikan hasil pengembangan LKPD menggunakan pendekatan saintifik pada materi SPLDV.

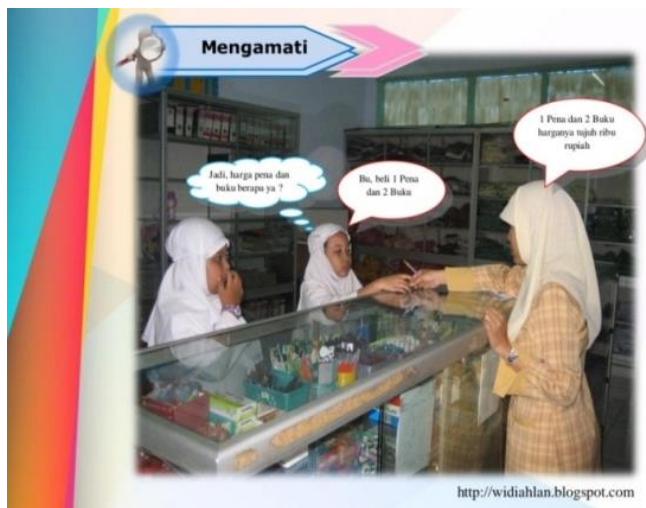

Gambar 1. Mengamati

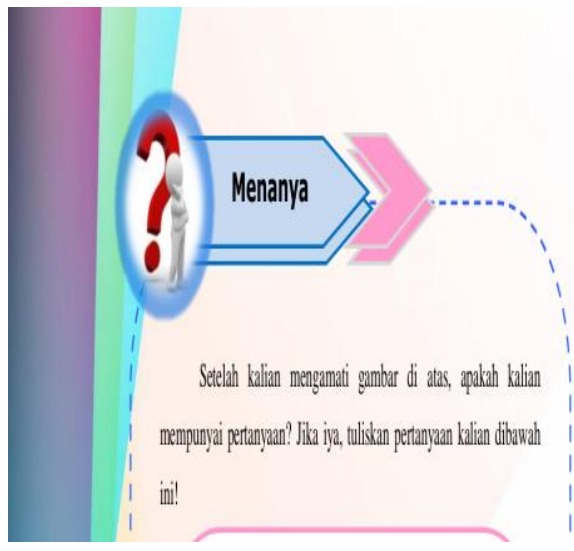

Gambar 3. Menanya

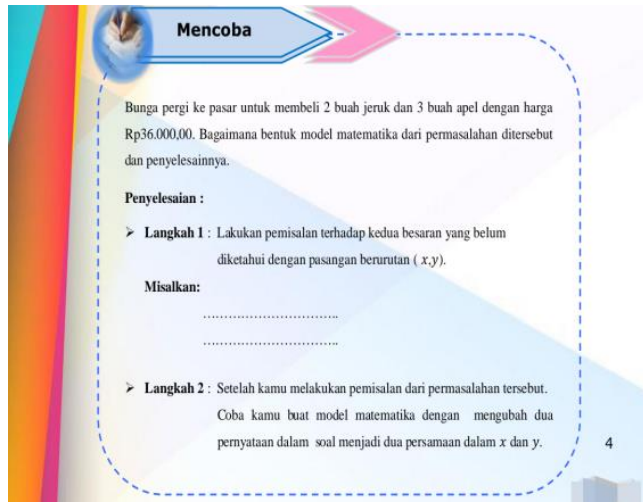

Gambar 2. Mencoba

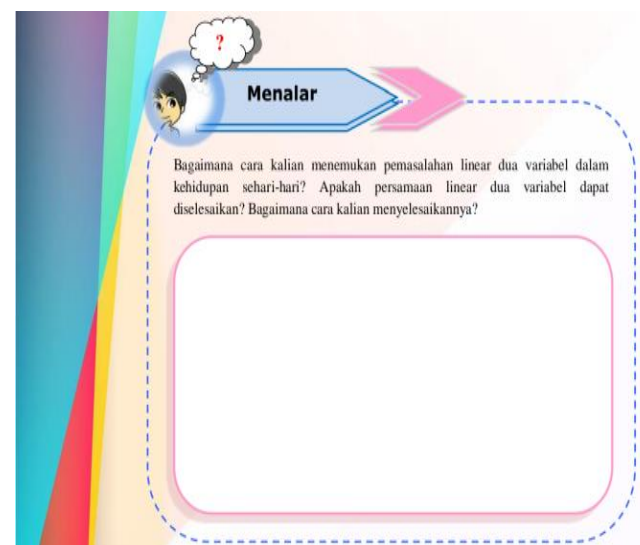

Gambar 4. Menalar

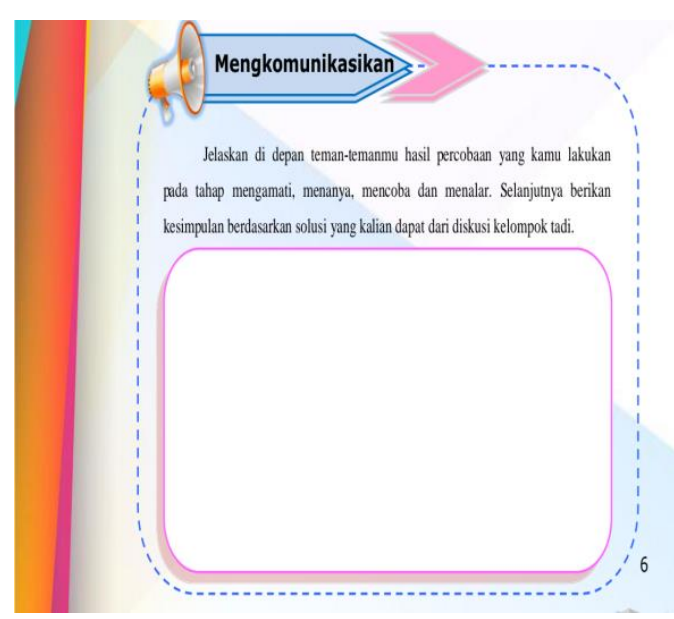

Gambar 5. Mengkomunikasikan 


\section{SIMPULAN DAN SARAN}

Penelitian pengembangan ini menghasilkan Lembar Kerja Peserta Didik (LKPD) yang valid dan praktis menggunakan pendekatan Saintifik. LKPD dikategorikan valid dengan skor rata-rata 3,37 ditentukan berdasarkan hasil penilaian oleh tiga pakar ahli (ahli materi, ahli bahasa dan ahli media) dengan skor masimal 4,00. Sedangkan kepraktisan LKPD menunjukkan rata-rata skor sebesar 3,31 yang ditentukan berdasarkan hasil respon peserta didik terhadap LKPD, sehingga LKPD dapat dikategorikan "Praktis".

Lembar Kerja Peserta Didik (LKPD) yang dikembangkan dalam penelitian ini dapat dijadikan salah satu alternatif media pembelajaran oleh guru sebagai penunjang kegiatan pembelajaran matematika.

\section{DAFTAR PUSTAKA}

Devi, P.K., Sofiraeni, R., dan Khairuddin. 2009. Pengembangan Perangkat Pembelajaran. Jakarta: Pusat Pengembangan dan Pemberdayaan Pendidik dan Tenaga Kependidikan IPA.

Hosnan. 2014. Pendekatan Saintifik dan Kontekstual dalam Pembelajaran Abad 21. Bogor: Ghalia Indonesia.

Ine, M.E. 2015. Penerapan Pendekatan Scientific Untuk Meningkatkan Prestasi Belajar Siswa Pada Mata Pelajaran Ekonomi Pokok Bahasan Pasar. Makalah Pada Prosiding Seminar Nasional Universitas Negeri Surabaya, Surabaya, 9 Mei 2015. Hal: 269-285.

Istikharah, R. dan Simatupang, Z. 2017. Pengembangan Lembar Kegiatan Peserta Didik (LKPD) Kelas X SMA/MA Pada Materi Pokok Protista Berbasis Pendekatan Ilmiah. Jurnal Pendidikan Matematika dan Sains, Vol. 12(1) : 3138.

Kemendikbud. 2013. Pendekatan Scientific (Ilmiah) dalam Pembelajaran. Jakarta: Pusbangprodik.

Mulyoto. 2013. Strategi Pembelajaran di Era Kurikulum 2013. Jakarta: Prestasi Putrakarya.

Pansa, H.E. 2017. Pengembangan LKPD dengan Model Problem Based Learning (PBL) Untuk Meningkatkan Kemampuan Komunikasi Matematis Siswa. Makalah Pada Prosiding Seminar Nasional Matematika dan Pendidikan Matematika UIN Raden Intan Lampung, Lampung, 16 Mei 2017. Hal: 229238 ISSN : 2579-9444.

Ramdani, Y. 2012. Pengembangan Instrumen dan Bahan Ajar untuk Meningkatkan Kemampuan Komunikasi, Penalaran dan Koneksi Matematis dalam Konsep Integral. Jurnal Penelitian Pendidikan, Vol. 13(1) : 44-52.

Rusman, M. 2017. Belajar dan Pembelajaran Berorientasi Standar Proses Pendidikan. Jakarta: Kencana.

Shoimin, A. 2014. 68 Model Pembelajaran Inovatif dalam Kurikulum 2013. Yogyakarta: Ar-Ruzz Media. 